\title{
Relative importance of kelps and fucoids as substrata of the invasive epiphytic bryozoan Membranipora membranacea in Nova Scotia, Canada
}

\author{
Alana F. Yorke ${ }^{1}$, Anna Metaxas ${ }^{2, *}$ \\ ${ }^{1}$ Department of Biology, and ${ }^{2}$ Department of Oceanography, Dalhousie University, Halifax, Nova Scotia B3H R2, Canada
}

\begin{abstract}
The successful establishment of invasive species is partly dependent upon their ability to utilize effectively local resources available in the invaded ecosystem. In the rocky subtidal habitats of Nova Scotia, Canada, the invasive epifaunal bryozoan Membranipora membranacea occurs in high abundance on kelps, which offer high space availability but are highly dynamic. However, this bryozoan also occurs on algae other than kelps, including Fucus species, which provide low space availability but higher stability than kelp. Previous research has focussed on population dynamics of the bryozoan on kelps, and the role of fucoids remains unknown. We quantified settlers and colony cover of M. membranacea on the kelps Saccharina latissima and Laminaria digitata (both native), and on Fucus evanescens (native) and F. serratus (introduced), at 4 sites in Nova Scotia, at various stages critical to the population dynamics of the bryozoan. The relative importance of kelp and fucoid substrata varied both intra- and interannually, as well as spatially. Settlement was higher on kelps than on Fucus spp. at sites where kelps were abundant; however, the abundance of settlers on Fucus spp. was similar to or greater than that on kelps at sites where kelps were sparse or spatially separated from Fucus spp. During the period of high colony cover in late autumn, cover was highest on L. digitata and lowest on Fucus spp. across all sites. After the winter, $M$. membranacea cover decreased by an order of magnitude on kelps, but remained stable on Fucus spp., suggesting high overwinter survival on fucoid algae. While kelps provide spatial resources for seasonal peaks in abundance of the invasive bryozoan, refuges can preserve local populations at certain times. For example, Fucus spp. provides an important refuge for overwintering colonies, particularly where defoliation of kelps has been extensive, and characteristics of this substratum probably facilitate early reproduction and local spread. Understanding the role of different components of an invaded ecosystem in the population dynamics of the introduced species can invoke possible mechanisms of successful establishment, spread and persistence.
\end{abstract}

KEY WORDS: Invasive species $\cdot$ Population dynamics $\cdot$ Benthic colonial organisms $\cdot$ Rocky subtidal habitats $\cdot$ Membranipora membranacea $\cdot$ Fucoids $\cdot$ Kelp $\cdot$ Refuge

\section{INTRODUCTION}

Invasive species possess a number of attributes that can enhance their spread, establishment and persistence in a variety of geographical and ecological settings. For example, adaptations for long-distance dispersal enable species to reach new regions at broad spatial scales, and breadth of ecological tolerance al- lows them to succeed in different habitats (Ricciardi \& Rasmussen 1998). Within nonnative communities, the ability to rapidly produce propagules enables local spread (Sakai et al. 2001), and species that can expand by asexual or clonal growth can quickly use available resources to increase their abundance (Wright \& Davis 2006). For an introduced marine epifaunal organism, such attributes may enable colo- 
nization of both stable and dynamic host substrata, facilitating temporal persistence, as well as spatial dominance in nonnative habitats.

Membranipora membranacea is an invasive, colonial, encrusting bryozoan that has caused considerable changes to the dynamics of rocky subtidal habitats of the northwest Atlantic Ocean. The native ranges of $M$. membranacea are in the Pacific and northeast Atlantic oceans, but it was first recorded in the Gulf of Maine, USA, in the 1980s (Walters \& Wethey 1986, Lambert et al. 1992), where it established itself as the dominant epifauna on laminarian kelps within 2 yr (Berman et al. 1992). M. membranacea was probably introduced from Europe and has since spread to the Atlantic coast of Nova Scotia, Canada, where it was first observed in Mahone Bay and St. Margarets Bay in 1992 (Scheibling et al. 1999, Schwaninger 1999). In its introduced range, colonies of $M$. membranacea encrust the blades of native kelps, which reduces their ability to withstand breakage (Krumhansl et al. 2011), and in years of population outbreaks of $M$. membranacea, kelp beds can be severely defoliated in autumn storms (Berman et al. 1992, Lambert et al. 1992, Scheibling et al. 1999, Saunders \& Metaxas 2008, Scheibling \& Gagnon 2009). Furthermore, an invasive green alga, Codium fragile, colonizes spaces opened by defoliation and, once established, can prevent recolonization by kelps (Levin et al. 2002, Scheibling \& Gagnon 2006).

Outbreaks of Membranipora membranacea have been partially linked to early timing and high rates of settlement after warm winters in combination with high colony growth in warm autumns (Saunders et al. 2010). Larvae of $M$. membranacea can be induced to settle by chemical cues and are reported to exhibit preference for kelp species, such as Saccharina latissima (Seed 1976, Stricker 1989), although the mechanisms behind this preference have not been demonstrated. However, the physical structure of kelp bed canopies may also influence patterns of settlement. For example, larvae can settle in high abundance on kelp fronds upon encounter and never reach understory species of algae beneath the kelp canopy (Bernstein \& Jung 1979, Duggins et al. 1990).

Kelps are highly dynamic substrata for epiphytic organisms. In Nova Scotia, kelps can sustain significant losses of biomass in autumn and winter storms. Additionally, they reach maximum growth rates in winter and early spring, during which fronds are completely replaced through rapid basal growth and distal erosion (Mann 1972, 1973). Populations of Membranipora membranacea are greatly affected by kelp dynamics. Settlers of M. membranacea on kelp increase in abundance throughout summer and autumn, reaching high rates of settlement over a short period (weeks) (Saunders \& Metaxas 2007). New recruits mature and colonies grow throughout late summer and autumn, and colony cover reaches its peak in late autumn, prior to mortality from kelp breakage and colony senescence in late autumn and winter (Saunders \& Metaxas 2008, 2009b). Some colonies persist through winter when growth is insignificant in low temperatures, and growth and reproduction resume with warming water temperatures in early summer (Saunders \& Metaxas 2009b, Saunders et al. 2010). Early research in this region suggested that $M$. membranacea may contribute to its own decline through reduction in kelp abundance by defoliation (Levin et al. 2002); however, nearly 2 decades after its recorded arrival, $M$. membranacea remains in these habitats as an abundant epifaunal species (Saunders \& Metaxas 2008, Scheibling \& Gagnon 2009, Watanabe et al. 2009).

Previous research in the northwest Atlantic Ocean has focussed on the occurrence of Membranipora membranacea on kelps, specifically Saccharina latissima (formerly S. longicruris; McDevit \& Saunders 2010) and Laminaria digitata (Lambert et al. 1992, Levin et al. 2002, Scheibling \& Gagnon 2006, 2009, Saunders \& Metaxas 2007, 2008, 2009a,b). However, M. membranacea occurs on various biotic and abiotic substrata throughout its range and, in addition to various kelp species, it also occurs on other algae. In its native range (northwest Europe), $M$. membranacea is a component of the native bryozoan assemblage on Fucus serratus (Ryland \& Stebbing 1971, O'Connor et al. 1979, Walters \& Wethey 1986), and has been reported on Ascophyllum nodosum and Halidrys siliquosa (Ryland 1959, 1962). In the northwest Atlantic, the occurrence of the bryozoan on algal substrata other than kelp has been reported, but only qualitatively, on Fucus evanescens and Chondrus crispus in northern New England, USA (Walters \& Wethey 1986), on C. fragile and Desmarestia aculeata in the Gulf of Maine (Harris \& Tyrrell 2001) and on F. evanescens, F. serratus, A. nodosum, C. crispus and C. fragile in Nova Scotia (Saier \& Chapman 2004, Watanabe et al. 2009, Yorke \& Metaxas 2011). The importance of Fucus species as a substratum for $M$. membranacea in its introduced range has not been quantified to date.

Of the fucoid substrata, Fucus evanescens is distributed widely throughout Nova Scotia in shallow subtidal habitats, and F. serratus is dominant in localized areas of the region, having been introduced to the province in the late 19th century (Edelstein et al. 
1971). These algae likely provide a more stable substratum for epifauna than kelp, as they have much lower intra-annual variation in biomass and slower growth rates (Mann 1973, McCook \& Chapman 1991). Additionally, these species may serve as vectors for local-scale spread of Membranipora membranacea along the shore in areas where kelps are absent or sparse (Watanabe et al. 2009). Defoliation of colonized kelp blades potentially affects the populations of $M$. membranacea, both through reduction of the adult population and through removal of preferred settlement substrata. However, if $M$. membranacea can successfully settle, grow and overwinter on Fucus species in subtidal communities, a reduction in kelp abundance will not necessarily result in bryozoan decline as suggested by Levin et al. (2002).

In this study, we examined the relative importance of 2 abundant kelp species and 2 Fucus species as substrata of the introduced epifaunal bryozoan Membranipora membranacea in Nova Scotia. To determine whether settlement varies between kelp and fucoid species, we quantified settlers, both early in the settlement period and near the peak of settlement, on Saccharina latissima, Laminaria digitata, Fucus evanescens and F. serratus. We sampled 4 sites that differ in kelp abundance and distribution. Fucoid algae may provide alternative substrata for M. membranacea settlers when kelps are sparse, particularly when rates of settlement are high and space on kelps may become limited. To compare the spatial extent and survival of colonies of $M$. membranacea between these kelp and fucoid species, we measured colony cover during the period of peak abundance in autumn and at the end of winter. We hypothesized that where recruitment and growth occur on species other than kelp, colony cover will probably persist on these stable substrata throughout late autumn and winter, providing adult populations in the beginning of the following season. Post-winter cover on fucoid algae may be relatively high compared with kelps, particularly where substantial defoliation of kelps has occurred. Our results will allow us to determine the contribution of fucoid algae to settlement, growth and overwintering of colonies of $M$. membranacea. The occurrence of $M$. membranacea on Fucus has been recorded in the native range of this invasive bryozoan; if significant, such an occurrence may also allow an important refuge in the bryozoan's introduced range, particularly where this species has caused defoliation of kelps.

\section{MATERIALS AND METHODS}

\section{Study sites}

We sampled 4 sites in and near St. Margarets Bay, Nova Scotia (Fig. 1), where the population dynamics of Membranipora membranacea have been previously studied on kelps (Saunders \& Metaxas 2007, 2008, 2009a, 2009b, Scheibling \& Gagnon 2009). Feltzen South $\left(44^{\circ} 19.9^{\prime} \mathrm{N}, 64^{\circ} 16.9^{\prime} \mathrm{W}\right)$ is near the
Fig. 1. Study area on the southern shore of Nova Scotia, Canada, showing sampling sites in Lunenburg Bay (Feltzen South), St. Margarets Bay (Birchy Head and Paddy's Head) and Pennant Bay (Sandy Cove)

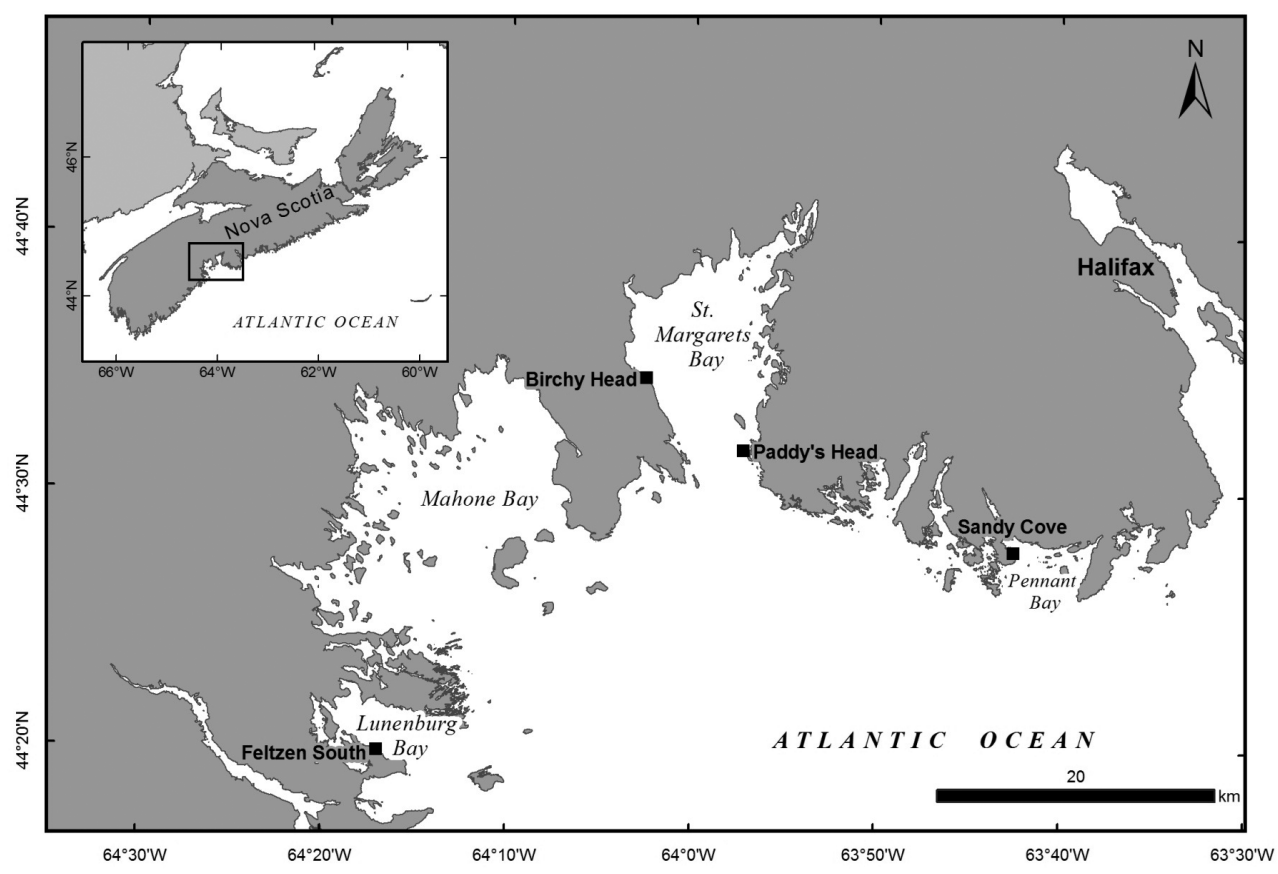


mouth of Lunenburg Bay, $30 \mathrm{~km}$ southwest of St. Margarets Bay. The site has a gently sloping bedrock seabed with a steep bedrock ridge offshore. Birchy Head $\left(44^{\circ} 34.5^{\prime} \mathrm{N}, 64^{\circ} 02.5^{\prime} \mathrm{W}\right)$ is on the western shore of St. Margarets Bay, and consists of a moderately sloping granite seabed with boulders and cobbles. Paddy's Head $\left(44^{\circ} 31.6^{\prime} \mathrm{N}, 63^{\circ} 57.2^{\prime} \mathrm{W}\right)$, on the eastern shore of St. Margarets Bay, includes a steeply sloping exposed outer wall, as well as a more sheltered shoreward cove. Sandy Cove $\left(44^{\circ} 27.8^{\prime} \mathrm{N}\right.$, $63^{\circ} 42.5^{\prime} \mathrm{W}$ ) is $20 \mathrm{~km}$ east of St. Margarets Bay at the mouth of Terence Bay in Pennant Bay. The site includes an outer slope with bedrock ridges, as well as a gently sloping sheltered inner cove with a cobble bottom. All sites are characterized by mixed kelp beds, dominated by Saccharina latissima and Laminaria digitata. Species of Fucus are also present throughout the study area, with $F$. serratus occurring at Feltzen South and F. evanescens at Birchy Head, Paddy's Head and Sandy Cove.

Access of settling larvae to algae other than kelp may be affected by kelp abundance and distribution if kelp act as 'filters' of settlers resulting in horizontal (as in our study sites) or vertical zonation (Bernstein \& Jung 1979); consequently, sites were selected to include variation in the openness of the kelp canopy. Feltzen South and Birchy Head were chosen to represent open canopies; kelps are spatially separated from Fucus at Feltzen South and they were sparse at Birchy Head during sampling. Paddy's Head and Sandy Cove were selected as sites with abundant kelp and closed canopies. Since Birchy Head and Paddy's Head are both in St. Margarets Bay, we assumed they share the same larval source and timing of settlement.

\section{Sample collection}

Sampling was designed to capture different stages in the annual population cycle of Membranipora membranacea, based on the known population dynamics of the species in the region (Saunders \& Metaxas 2007, 2008, 2009b). We measured early settlers (August 2008), peak settlers (October 2008), prewinter cover (November to December 2008) and postwinter cover (July 2008 and July 2009). We describe early settlers as those that occur prior to the major settlement event, when settlers are sparse but detectable and increasing in abundance. Peak settlers are those that occur during the period of highest settlement. Prewinter cover describes the spatial extent of colonies at the end of the periods of settle- ment and growth and before the onset of slow growth and mortality due to senescence. Postwinter cover describes the spatial extent of colonies that have overwintered successfully and that were censused prior to the accelerated growth associated with increasing temperature.

At each site and each stage, abundance of Saccharina latissima, Laminaria digitata, and Fucus spp. (F. serratus at Feltzen South, F. evanescens at all other sites) were sampled in 8 to 10 randomly selected $1 \mathrm{~m}^{2}$ quadrats along transects using SCUBA. Transects were positioned within the zone of highest abundance for each algal taxon at each site and were situated to include the range of depths over which each taxon occurred to a maximum depth of $8 \mathrm{~m}$ in most instances (except to $14 \mathrm{~m}$ on one occasion) (Table 1). If the alga of interest was absent from a quadrat, contiguous quadrats were sampled until the alga was found. The sampled area was then pooled across all contiguous quadrats. For postwinter cover, we sampled only algae that were encrusted by Membranipora membranacea, whereas for all other periods, all thalli of S. latissima, L. digitata and Fucus spp. were collected from each quadrat for quantification of kelp abundance and algal biomass (see below). Algae were transferred to dry tubs at the surface and transported to the laboratory for storage in aquaria with ambient running seawater until processing was completed.

Table 1. Fucus spp., Laminaria digitata and Saccharina latissima. Details of sampling distributions of algal taxa at each site. Orientation of transect is relative to the shoreline

\begin{tabular}{|lcl|}
\hline $\begin{array}{l}\text { Site } \\
\text { Algal species }\end{array}$ & $\begin{array}{c}\text { Depth } \\
\text { range }(\mathrm{m})\end{array}$ & $\begin{array}{l}\text { Orientation of } \\
\text { transect }\end{array}$ \\
\hline Feltzen South & & \\
Fucus serratus & $2.8-6.2$ & $\begin{array}{l}\text { Perpendicular } \\
\text { Laminaria digitata }\end{array}$ \\
Saccharina latissima & $5.0-7.8$ & Parallel \\
Birchy Head & $5.9-8.0$ & Parallel \\
Fucus evanescens & $0.1-0.8$ & Parallel \\
Laminaria digitata & $0.1-1.5$ & Parallel \\
Saccharina latissima & $1.1-8.2$ & Perpendicular \\
Paddy's Head & & \\
Fucus evanescens & $0.1-3.1$ & Parallel \\
Laminaria digitata & $2.5-14$ & Perpendicular \\
Saccharina latissima & $2.3-14$ & Perpendicular \\
Sandy Cove & & \\
Fucus evanescens & $0.2-3.7$ & Parallel \\
Laminaria digitata & $0.9-7.1$ & Perpendicular \\
Saccharina latissima & $0.6-7.1$ & Perpendicular \\
\hline
\end{tabular}




\section{Quantification of Membranipora membranacea}

For early settlers, all settlers (defined as in Saunders \& Metaxas 2007 as any colony with fewer than 2 zooid rows) were counted on a subsample of 1 to 5 kelp thalli, or $\sim 0.5 \mathrm{~m}^{2}$ surface area for Fucus spp., from each quadrat. For peak settlers (October 2008), we only counted settlers on one randomly chosen quarter of each kelp blade (as in Saunders \& Metaxas 2007) and one side of Fucus thalli of subsampled algae. For prewinter and postwinter colony cover, all mature colonies of Membranipora membranacea on each thallus were traced and photographed with a Nikon Coolpix 995 digital camera, and surface area was measured with SigmaScan Pro Image Analysis 5.0 (SPSS). Processing generally occurred within 1 to $8 \mathrm{~d}$ of sampling, with the exception of peak settlers on Fucus, which were quantified within 20 to $26 \mathrm{~d}$. Settlers and colonies did not grow while in aquaria, indicating that the length of time held prior to processing did not affect results.

The surface area of algal thalli was also measured by using image analysis of photographs in the same manner as for tracings of Membranipora membranacea colonies. Uncolonized algal surface area was calculated in October 2008 as the difference between thallus surface area and area of mature colonies. For Saccharina latissima, surface area cannot be determined from a single view in 2 dimensions because of blade crenulations. For this species, thalli were cut up and the fragments laid flat for photography and analysis, as described above. Several (6 to 13) thalli from a range of conditions (2 sites for each of August, October and November to December 2008) were used to calculate the ratio of fragment surface area to intact surface area for S. latissima. Analysis of the effects of site and period on these ratios revealed a significant effect of period (2-way ANOVA; Site: $F_{2,50}=2.061, \mathrm{p}=0.138$; Period: $F_{2,50}=$ 5.772, $\mathrm{p}=0.006$; Site $\times$ Period: $F_{1,50}=0.119, \mathrm{p}=$ 0.732). Simple linear regressions were therefore generated for each period to correct intact surface area measurements for S. latissima.

Because the relative abundance, biomass and consequently available surface area of the different algal species varied among sites (and for kelps also among times), we calculated the abundance of settlers and prewinter colony cover of Membranipora membranacea on each algal species per unit area of seabed (in addition to per unit area of alga), which allowed us to examine the relative contribution of each algal species. To obtain total surface area of alga per unit area seabed, we developed indices of surface area to bio- mass. Up to 5 thalli (or $\sim 0.5 \mathrm{~m}^{2}$ surface area, $\sim 140 \mathrm{~g}$ wet weight, for Fucus spp.) from each quadrat at each of these sampling periods were weighed in the laboratory using an electronic balance (accuracy, $0.001 \mathrm{~g}$ ) and their surface area was measured. From these measures, simple linear regressions of surface area with biomass were generated for each algal taxon at each sampling stage. During sampling, most quadrats contained 1 to 22 thalli for Saccharina latissima and 1 to 10 thalli for Laminaria digitata. For quadrats with fewer than 5 thalli (or <140 g Fucus spp.), total surface area per quadrat was measured in the laboratory, as described above. For quadrats with more than 5 thalli (or >140 g Fucus spp.), total algal mass in each quadrat was measured in the field by using a spring balance (accuracy, $25 \mathrm{~g}$ ), and the linear relationships obtained in the laboratory were then used to calculate algal surface area per unit area seabed.

\section{Statistical analyses}

The effects of site (fixed factor, 4 levels: Feltzen South, Birchy Head, Paddy's Head and Sandy Cove) and period (fixed factor, 3 levels: August, October and November to December 2008) were examined on the abundance of kelp (no. thalli $\mathrm{m}^{-2}$ seabed) for each of Saccharina latissima and Laminaria digitata, and on biomass ( $\mathrm{kg} \mathrm{m}^{-2}$ seabed) for Fucus spp., using 2way ANOVA. Site was a fixed factor because sites were selected for their locations (inside and outside St. Margarets Bay) and for characteristics of kelp canopies. Period was also a fixed factor because sampling corresponded with specific events in the annual population cycle of Membranipora membranacea.

The effects of algal taxon (fixed factor, 3 levels: Saccharina latissima, Laminaria digitata and Fucus spp.) and site were examined by 2-way ANOVA for each of the following variables: abundance of bryozoan early settlers as no. $\mathrm{m}^{-2}$ alga (August 2008) and abundance of peak settlers as no. $\mathrm{m}^{-2}$ alga (October 2008); abundance of peak settlers as no. $\mathrm{m}^{-2}$ uncolonized alga (October 2008); abundance of early settlers as no. $\mathrm{m}^{-2}$ seabed (August 2008) and abundance of peak settlers as no. $\mathrm{m}^{-2}$ seabed (October 2008); prewinter colony cover as $\mathrm{cm}^{2} \mathrm{~m}^{-2}$ alga and prewinter colony cover as $\mathrm{cm}^{2} \mathrm{~m}^{-2}$ seabed (November to December 2008). The effects of algal taxon, site and year (random factor, 2 levels: 2008 and 2009) on postwinter colony cover as $\mathrm{cm}^{2} \mathrm{~m}^{-2}$ seabed (July 2008 and 2009) were examined by 3-way ANOVA. Specific differences between pre- and postwinter 
colony cover as $\mathrm{cm}^{2} \mathrm{~m}^{-2}$ seabed were examined with a 3-way ANOVA, with algal taxon, site and season (fixed factor: November to December 2008 and July 2009) as the main factors.

For these analyses, the following transformations were applied to reduce heterogeneity of variances: $\log (x)$ for kelp abundance; $\log (x+0.01)$ for early settler abundance, prewinter colony cover and postwinter colony cover; and $\log (x+1)$ for peak settler abundance. Homogeneity of variance (Levene's test, $\mathrm{p}<$ 0.05) was not achieved through transformation for the following: Laminaria digitata abundance $\mathrm{m}^{-2}$ seabed, Fucus spp. biomass $\mathrm{m}^{-2}$ seabed, early settler abundance $\mathrm{m}^{-2}$ algae and $\mathrm{m}^{-2}$ seabed, prewinter colony cover $\mathrm{m}^{-2}$ alga and $\mathrm{m}^{-2}$ seabed, and postwinter colony cover $\mathrm{m}^{-2}$ seabed (2008 and 2009); therefore a more conservative $\alpha_{\text {critical }}=0.01$ was used for these analyses. According to the Shapiro-Wilk test $(\mathrm{p}<0.05)$, early settler abundance $\left(\mathrm{m}^{-2}\right.$ alga and $\mathrm{m}^{-2}$ seabed), prewinter colony cover $\left(\mathrm{m}^{-2}\right.$ alga and $\mathrm{m}^{-2}$ seabed), and postwinter colony cover (2008 and 2009) were not distributed normally; however, ANOVA is robust to deviations from normality (Zar 1999). Statistical analyses were conducted by using SPSS 15.0. Where appropriate, homogeneous subsets were identified using Tukey's Honestly Significant Difference (HSD) tests.

\section{RESULTS}

\section{Abundance of kelps and fucoids and distribution of algae}

At Feltzen South, kelps and Fucus are spatially separated; the site includes an extensive, dense meadow of $F$. serratus at $\sim 3$ to $6 \mathrm{~m}$ depth, and both kelp species occur primarily on a steep bedrock ridge offshore, 10 s of metres from the Fucus meadow at $\sim 5$ to $10 \mathrm{~m}$ depth. At Birchy Head, kelps occur sparsely at $<11 \mathrm{~m}$ depth (with Laminaria digitata occurring primarily at $<2 \mathrm{~m}$ depth) and $F$. evanescens occurring in adjacent shallower areas $(<1 \mathrm{~m})$ with a patchy distribution. The outer wall at Paddy's Head is dominated by abundant Saccharina latissima and L. digitata at depths $>2 \mathrm{~m}$, and $F$. evanescens occurs sparsely 10 s of metres shoreward at depths $<3 \mathrm{~m}$. At Sandy Cove, the outer slope has luxuriant kelp beds of $S$. latissima and $L$. digitata at depths $\sim 1$ to $10 \mathrm{~m}$, and $F$. evanescens occurs nearby in the inner cove (within 10s of metres) at $<4 \mathrm{~m}$ depth.

The measured patterns in abundance of kelp in 2008 indicated that Birchy Head and Feltzen South were sites with canopies that were more open than those at Paddy's Head and Sandy Cove. Abundance of Saccharina latissima was significantly lower at both Birchy Head and Feltzen South than at Paddy's Head and Sandy Cove, and abundance of Laminaria digitata was significantly lower at Birchy Head than at Feltzen South and Paddy's Head (Fig. 2, Table 2). Abundance of both kelp species was greatest in October (Fig. 2, Table 2). Biomass of Fucus spp. was lower at Paddy's Head than at the other sites and higher in November and December than the other 2 periods (Fig. 2, Table 2).
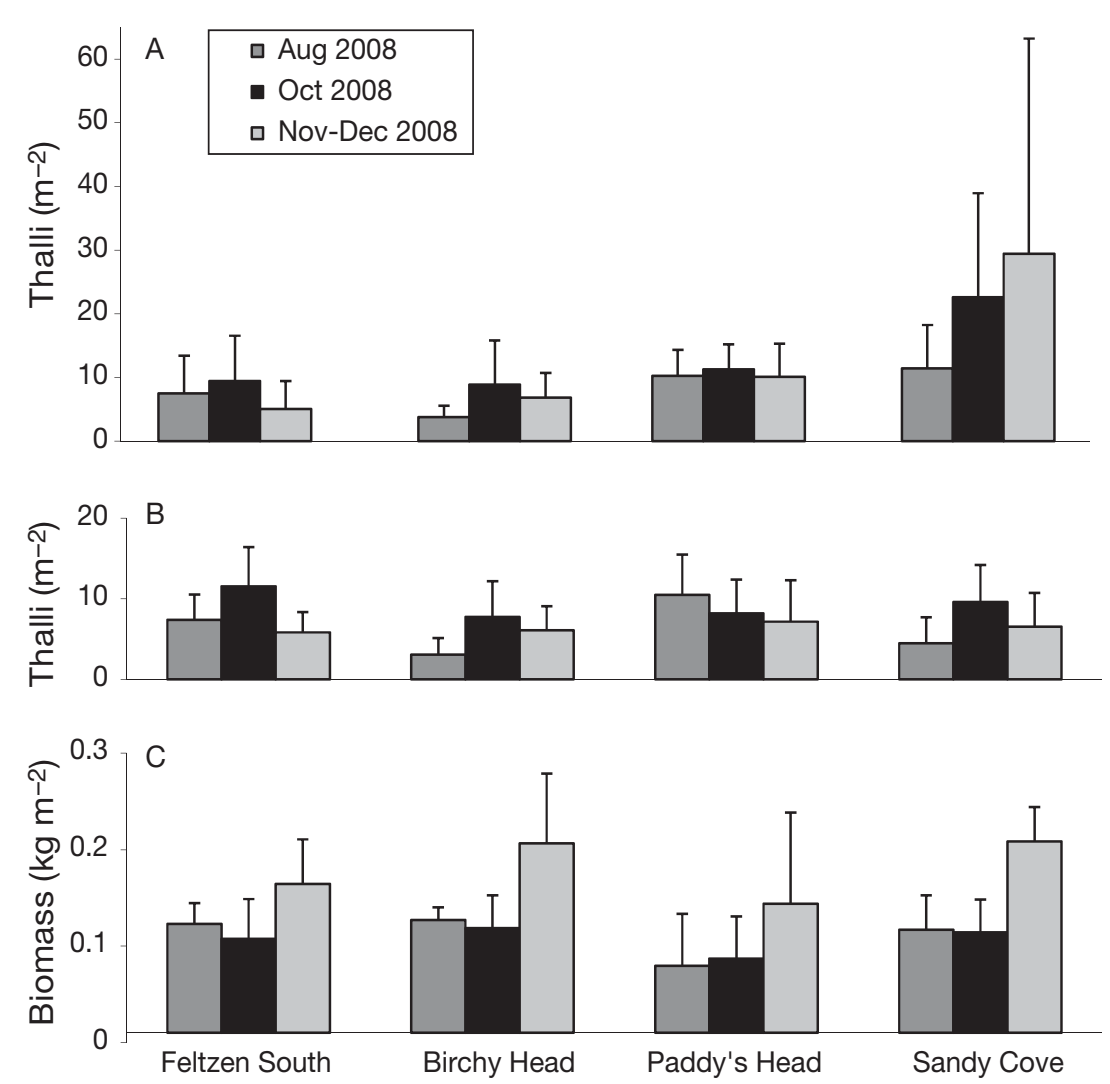

Fig. 2. Abundance (mean $+\mathrm{SD}$ ) of 2 species of kelps and biomass of fucoids at each of 4 sites on the southern shore of Nova Scotia in August 2008, October 2008 and November to December 2008. (A,B) Number of thalli per unit area of seabed for (A) Saccharina latissima ( $\mathrm{n}=7-11$ ) and (B) Laminaria digitata $(\mathrm{n}=$ 8-11). (C) Biomass per unit area of seabed for Fucus evanescens (Birchy Head, Paddy's Head and Sandy Cove) and F. serratus (Feltzen South) $(\mathrm{n}=8-10)$ 
Table 2.Two-way ANOVA examining the effects of site (fixed factor, 4 levels: Feltzen South, Birchy Head, Paddy's Head, Sandy Cove) and period (fixed factor, 3 levels: August 2008, October 2008, November to December 2008) on the abundance of kelp thalli (no. $\mathrm{m}^{-2}$ seabed). FS: Feltzen South; BH: Birchy Head; PH: Paddy's Head; SC: Sandy Cove. Bold font indicates significant $p$-values (Saccharina latissima, $\alpha=0.05$; Laminaria digitata and Fucus spp., $\alpha<0.01$, see 'Materials and methods'). Only significant differences in post hoc tests (Tukey's Honestly Significant Difference) are shown (at $\mathrm{p}<0.05)$

\begin{tabular}{|lcccl|}
\hline Effect & MS & \multicolumn{1}{c}{$F_{\mathrm{df}}$} & $\mathrm{p}$ & Tukey's HSD test \\
\hline S. latissima & & & & \\
Site & 1.369 & $17.20_{3,99}$ & $\mathbf{< . 0 0 1}$ & SC $>$ PH $>$ FS, BH \\
Period & 0.302 & $3.801_{2,99}$ & $\mathbf{0 . 0 2 6}$ & Oct $>$ Aug \\
Site $\times$ Period & 0.141 & $1.767_{6,99}$ & 0.114 & \\
Error & 0.080 & & & \\
L. digitata & & & & \\
Site & 0.440 & $4.920_{3,99}$ & $\mathbf{0 . 0 0 3}$ & FS, PH $>$ BH \\
Period & 0.544 & $6.082_{2,99}$ & $\mathbf{0 . 0 0 3}$ & Oct $>$ Nov-Dec, Aug \\
Site $\times$ Period & 0.268 & $2.994_{6,99}$ & 0.010 & \\
Error & 0.089 & & & \\
Fucus spp. & & & & \\
Site & 0.013 & $5.435_{3,103}$ & $\mathbf{0 . 0 0 2}$ & SC, FS, BH > PH \\
Period & 0.066 & $27.71_{2,103}$ & $<\mathbf{0 . 0 0 1}$ & Nov-Dec $>$ Aug, Oct \\
Site $\times$ Period & 0.001 & $0.625_{6,103}$ & 0.710 & \\
Error & 0.002 & & & \\
\hline
\end{tabular}
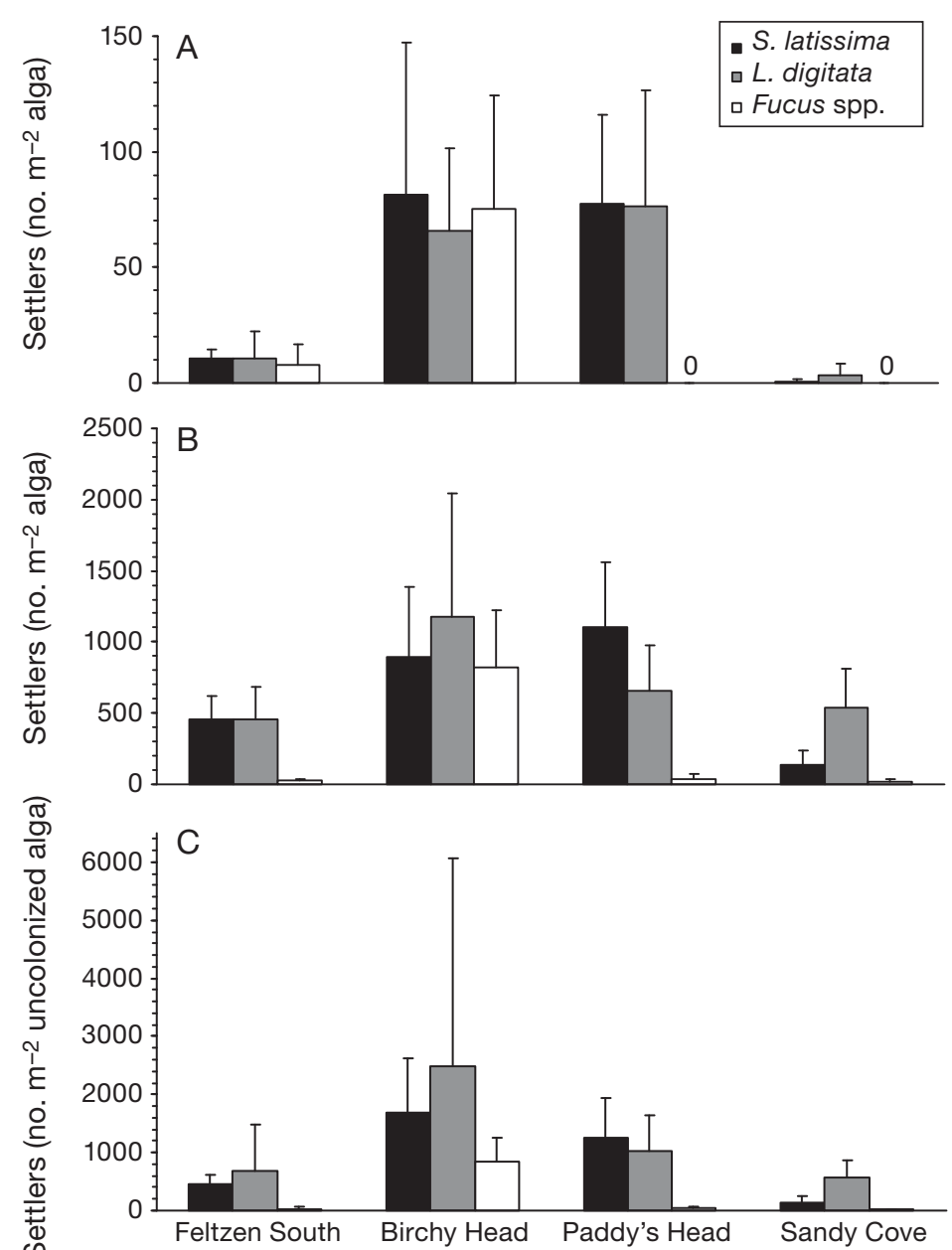

\section{Settlement of Membranipora membranacea}

Abundance of peak settlers of Membranipora membranacea was an order of magnitude greater than that of early settlers (Fig. 3). There were significant interactions between algal taxon and site for both early and peak settlers (Table 3). However, patterns in abundance among sites and algal taxa were generally consistent between early and peak settlers.

Settlers were generally more abundant on kelps than on Fucus spp. both during early and peak settlement stages at all sites except at Birchy Head, and no significant differences were apparent between Saccharina latissima and Laminaria digitata, except at Sandy Cove (Table 3). At Birchy Head, abundance of both early and peak settlers was similar on kelp and fucoid algae. Also, at Feltzen South, early settlers did not differ between Fucus spp. and L. digitata. Whereas settlement per unit area of alga was similar across sites on $S$. latissima (except at Sandy Cove), abundance of early and peak settlers on Fucus spp. was greatest at Birchy Head. Patterns in the abundance of peak settlers per unit area of uncolonized alga did not differ from those found for peak settlers per unit area of alga; however, the relationships among sites changed when the amount of uncolonized area was taken into account. Abundance per unit area of uncolonized alga was significantly greatest at Birchy Head for all algal taxa (Fig. 3C, Table 3).

Patterns of settler abundance per unit area of seabed among algal taxa were similar to those detected per unit area of alga in most cases for both early and peak settlers (Fig. 4,

Fig. 3. Membranipora membranacea. Abundance (mean $+\mathrm{SD}$ ) of settlers per unit area of alga on 3 algal taxa: Saccharina latissima, Laminaria digitata and Fucus spp. (F. evanescens at Birchy Head, Paddy's Head and Sandy Cove, and F. serratus at Feltzen South) at each of 4 sites on the southern shore of Nova Scotia. (A) Early settlers (August 2008, $\mathrm{n}=8-11$ ) and (B) peak settlers (October 2008, $\mathrm{n}=9-11$ ) per unit area of alga. (C) Peak settlers (October 2008, n = 9-11) per unit area of uncolonized alga, where 'uncolonized alga' is the area of thallus not occupied by mature colonies of M. membranacea 
Table 3. Two-way ANOVA examining the effects of algal taxon (fixed factor, 3 levels: Saccharina latissima, Laminaria digitata, Fucus spp.) and site (fixed factor, 4 levels: Feltzen South, Birchy Head, Paddy's Head, Sandy Cove) on abundance of early settlers (no. $\mathrm{m}^{-2}$ alga) in August 2008 and peak settlers (no. $\mathrm{m}^{-2}$ alga and no. $\mathrm{m}^{-2}$ uncolonized alga) in October 2008, of MembraniFeltzen South; BH: Birchy Head; PH: Paddy's Head; SC: Sandy Cove. Bold font indicates significant $p$-values, $\alpha=0.01$ (see 'Materials and methods').

Only significant differences in post hoc tests are shown (at $p<0.05$ )

\begin{tabular}{|c|c|c|c|c|}
\hline Effect & MS & $F_{\mathrm{df}}$ & $\mathrm{p}$ & Tukey's HSD test \\
\hline \multicolumn{5}{|c|}{ Early settlers (per unit area of alga) } \\
\hline Algal taxon & 21.79 & $35.02_{2,92}$ & $<0.001$ & $\begin{array}{l}\text { FS: } S l>F S \\
\text { PH: } S l, L d>F S \\
\text { SC: } L d>S l, F S\end{array}$ \\
\hline Site & 46.96 & $75.50_{3,92}$ & $<0.001$ & $\begin{array}{l}\text { Sl: } \mathrm{FS}, \mathrm{BH}, \mathrm{PH}>\mathrm{SC} \\
L d: \mathrm{BH}, \mathrm{PH}>\mathrm{FS}>\mathrm{SC} \\
\text { FS: } \mathrm{BH}>\mathrm{FS}>\mathrm{PH}, \mathrm{SC}\end{array}$ \\
\hline $\begin{array}{l}\text { Algal taxon } \times \text { Site } \\
\text { Error }\end{array}$ & $\begin{array}{l}9.135 \\
0.622\end{array}$ & $14.69_{6,92}$ & $<0.001$ & \\
\hline \multicolumn{5}{|c|}{ Peak settlers (per unit area of alga) } \\
\hline Algal taxon & 14.38 & $135.1_{2,108}$ & $<0.001$ & $\begin{array}{l}\text { FS, PH: } S l_{1} L d>F S \\
\text { SC: } L d>S l>F S\end{array}$ \\
\hline Site & 4.798 & $45.05_{3,108}$ & $<0.001$ & $\begin{array}{l}S I: \mathrm{FS}, \mathrm{BH}, \mathrm{PH}>\mathrm{SC} \\
F_{S}: \mathrm{BH}>\mathrm{FS}, \mathrm{PH}, \mathrm{SC}\end{array}$ \\
\hline $\begin{array}{l}\text { Algal taxon } \times \text { Site } \\
\text { Error }\end{array}$ & $\begin{array}{l}1.828 \\
0.107\end{array}$ & $17.16_{6,108}$ & $<0.001$ & \\
\hline \multicolumn{5}{|c|}{ Peak settlers (per unit area of uncolonized alga) } \\
\hline Algal taxon & 17.07 & $142.2_{2,108}$ & $<0.001$ & $\begin{array}{l}\text { As for peak settlers } \\
\text { (per unit area of alga) } \\
\text { for all sites }\end{array}$ \\
\hline Site & 6.306 & $52.52_{3,108}$ & $<0.001$ & $\begin{array}{l}S l: \mathrm{BH}, \mathrm{PH}>\mathrm{FS}>\mathrm{SC} \\
L d: \mathrm{BH}>\mathrm{FS}, \mathrm{SC} \\
\text { FS: } \mathrm{BH}>\mathrm{FS}, \mathrm{PH}, \mathrm{SC}\end{array}$ \\
\hline $\begin{array}{l}\text { Algal taxon } \times \text { Site } \\
\text { Error }\end{array}$ & $\begin{array}{l}1.495 \\
0.120\end{array}$ & $12.45_{6,108}$ & $<0.001$ & \\
\hline
\end{tabular}
pora membranacea. Sl: S. latissima; Ld: L. digitata; FS: Fucus spp.; FS:

not significantly. The abundance of peak settlers was significantly lower on Saccharina latissima than on both Laminaria digitata and $F$. evanescens at Birchy Head, which was probably due to low abundance of this kelp species at that site. Settlement varied among sites; on kelp, abundance of early settlers was generally lowest at Sandy Cove, and that of peak settlers was significantly greater at Paddy's Head than at Birchy Head. For Fucus spp., patterns in abundance of early and peak settlers per unit area of seabed were similar to those observed for abundance per unit area of algae, with the highest abundance occurring at Birchy Head.

\section{Pre- and postwinter cover of Membranipora membranacea colonies}

In general, the cover of Membranipora membranacea colonies per unit area of seabed was greater at the end of the growing season (November to December 2008) than at the end of winter (June 2009) for both kelp species and Fucus evanescens at most sites, except on F. serratus at Feltzen South where the opposite was observed (Figs. 5 \& 6, Table 5). In

Table 4). At the 2 sites where settlement occurred on Fucus spp. (Birchy Head and Feltzen South), mean abundance of early settlers per unit area of seabed was higher on Fucus than on kelps, although December 2008, cover of $M$. membranacea colonies was greatest on kelps at Paddy's Head and Sandy Cove, whereas in June 2009, it was greatest on Fucus spp. at 3 of 4 sites.

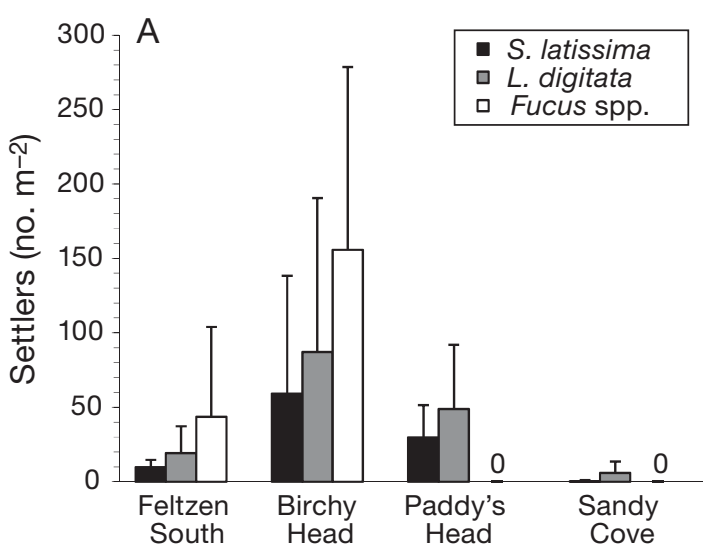

Fig. 4. Membranipora membranacea. Abundance (mean + SD) of settlers per unit area of seabed on each of 3 algal taxa: Saccharina latissima, Laminaria digitata and Fucus spp. (F. evanescens at Birchy Head, Paddy's Head and Sandy Cove, and F. serratus at Feltzen South) at each of 4 sites on the southern shore of Nova Scotia. (A) Early settlers (August 2008, $\mathrm{n}=8-11$ ) and

(B) peak settlers (October 2008, $\mathrm{n}=9-11$ ) 
Table 4. Two-way ANOVA examining the effects of algal taxon (fixed factor, 3 levels: Saccharina latissima, Laminaria digitata, Fucus spp.) and site (fixed factor, 4 levels: Feltzen South, Birchy Head, Paddy's Head, Sandy Cove) on abundance of early settlers (no. $\mathrm{m}^{-2}$ seabed) in August 2008 and peak settlers (no. $\mathrm{m}^{-2}$ seabed) in October 2008, of Membranipora membranacea. Abbreviations are as in Table 3 ; bold font indicates significant p-values, $\alpha=$ 0.01 (see 'Materials and methods'). Only significant differences in post hoc tests are shown (at $\mathrm{p}<0.05$ )

\begin{tabular}{|c|c|c|c|c|}
\hline Effect & MS & $F_{\mathrm{df}}$ & $\mathrm{p}$ & Tukey's HSD test \\
\hline \multicolumn{5}{|c|}{ Early settlers (per unit area of seabed) } \\
\hline Algal taxon & 13.39 & $15.74_{2,92}$ & $<0.001$ & $\begin{array}{l}\text { PH: } S l, L d>F_{S} \\
\text { SC: } L d>S l, F S\end{array}$ \\
\hline Site & 44.70 & $52.55_{3,92}$ & $<0.001$ & $\begin{array}{l}\text { Sl: FS, BH, } \mathrm{PH}>\mathrm{SC} \\
L d: \mathrm{BH}, \mathrm{PH}>\mathrm{SC} \\
\text { FS: } \mathrm{BH}>\mathrm{FS}>\mathrm{PH}, \mathrm{SC}\end{array}$ \\
\hline $\begin{array}{l}\text { Algal taxon } \times \text { Site } \\
\text { Error }\end{array}$ & $\begin{array}{l}9.214 \\
0.851\end{array}$ & $10.83_{6,92}$ & $<0.001$ & \\
\hline \multicolumn{5}{|c|}{ Peak settlers (per unit area of seabed) } \\
\hline Algal taxon & 12.34 & $46.55_{2,108}$ & $<0.001$ & $\begin{array}{l}\text { FS, SC: } S l, L d>F S \\
\text { BH: } L d, F S>S l \\
\text { PH: } S l>L d>F S\end{array}$ \\
\hline Site & 2.560 & $9.653_{3,108}$ & $<0.001$ & $\begin{array}{l}\text { Sl: } \mathrm{PH}>\mathrm{BH} \\
\text { FS: } \mathrm{BH}>\mathrm{FS}>\mathrm{PH}\end{array}$ \\
\hline Algal taxon $\times$ Site & 3.610 & $13.61_{6,108}$ & $<0.001$ & \\
\hline Error & 0.265 & & & \\
\hline
\end{tabular}
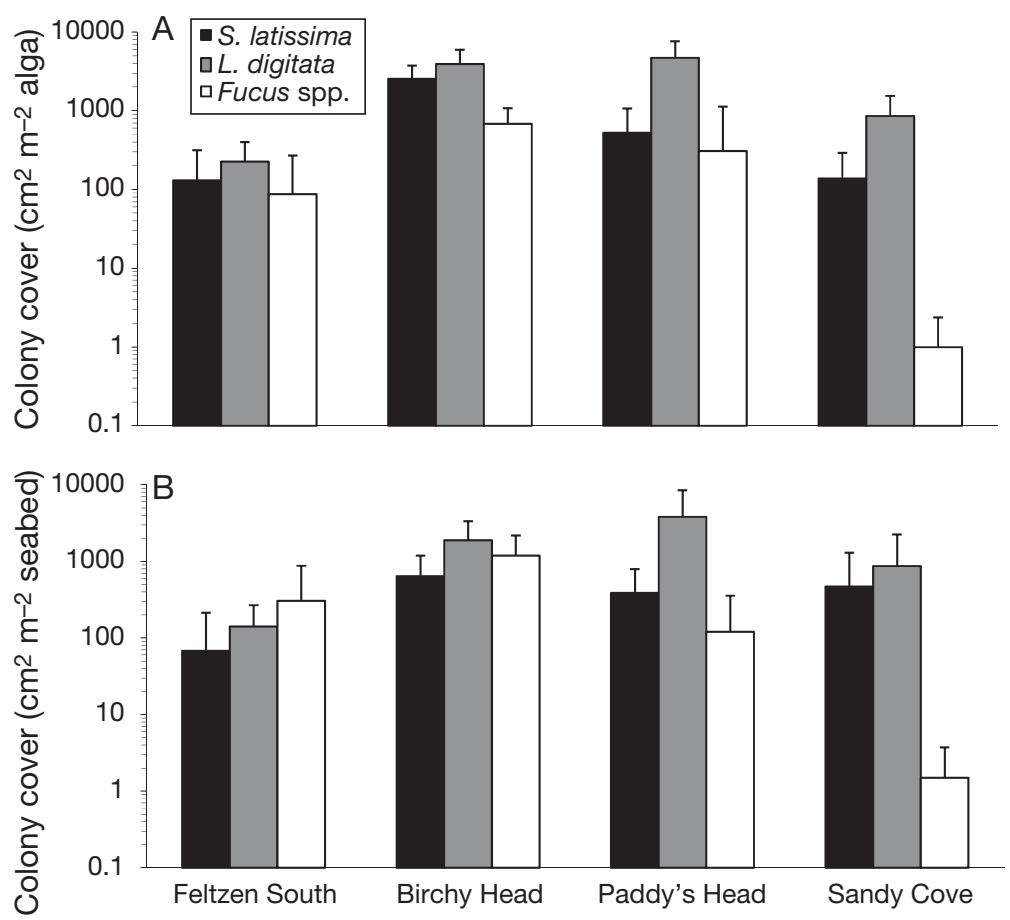

Fig. 5. Membranipora membranacea. Area (mean + SD) of prewinter colony cover of the bryzoan on 3 algal taxa: Saccharina latissima, Laminaria digitata and Fucus spp. (F. evanescens at Birchy Head, Paddy's Head and Sandy Cove, and F. serratus at Feltzen South) at each of 4 sites on the southern shore of Nova Scotia (November to December 2008, $n=9-10$ ) per (A) unit area of alga and (B) unit area of seabed
The cover of Membranipora membranacea colonies per unit area of alga and per unit area of seabed in November and December 2008 spanned orders of magnitude across sites (Fig. 5). Patterns in the cover of $M$. membranacea colonies were consistent among algal taxa across sites when quantified as both per unit area of alga and per unit area of seabed. Colony cover was significantly greatest on Laminaria digitata and lowest on Fucus spp. Prewinter cover was generally greater at Birchy Head than at the other sites (Table 6).

Following winter mortality, patterns of Membranipora membranacea colony cover also varied among sites and algal taxa, and between years (Fig. 6). There was a significant interaction among algal taxon, site and year on colony cover per unit area of seabed (Table 7). In both years, postwinter cover was either greater than or similar to that on Fucus spp. than on one or both kelps (Table 7). In both years, postwinter colony cover on Saccharina latissima did not vary across sites, whereas on Fucus spp. it was consistently greatest at Feltzen South.

\section{DISCUSSION}

We found that the invasive bryozoan Membranipora membranacea settles, grows and overwinters on Fucus spp. in its introduced range and that it occurs on these substrata at magnitudes significant to populations in Nova Scotia. There was substantial spatial and temporal variation in the abundance of $M$. membranacea, suggesting that the relative importance of kelp and Fucus spp. substrata at different stages of the population cycle of this bryozoan depends on various factors, such as larval supply and algal abundance and distribution, which can, in turn, vary temporally and spatially.

\section{Settlement}

At most sites, settlers were more abundant on kelps than on Fucus evanescens 


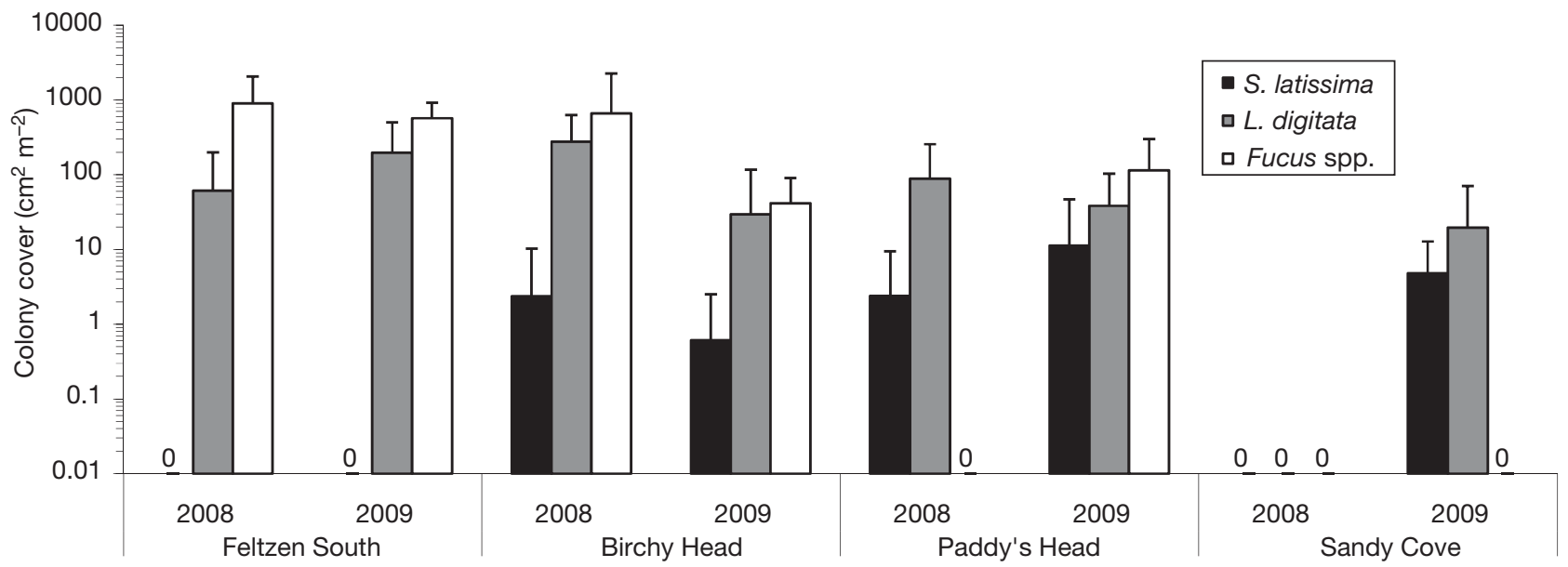

Fig. 6. Area (mean $+\mathrm{SD}$ ) of postwinter cover of colonies of Membranipora membranacea per unit area of seabed on 3 algal taxa: Saccharina latissima, Laminaria digitata and Fucus spp. (F. evanescens at Birchy Head, Paddy's Head and Sandy Cove, and F. serratus at Feltzen South) at each of 4 sites on the southern shore of Nova Scotia in July 2008 and July 2009 (n = 7-11)

(Paddy's Head and Sandy Cove) or F. serratus (at Feltzen South), except at Birch Head, which was the site with the lowest kelp abundance. When adjusted for algal abundance at a particular site, settler abundance generally was higher on Fucus spp. than on kelps at both Feltzen South and Birchy Head. At Feltzen South, high abundance of settlers per unit area of seabed can be attributed to the dense and extensive distribution of $F$. serratus there, supplying higher surface area per unit area of seabed than kelps.

For Membranipora membranacea, larvae are reported to settle preferentially on kelps (Seed 1976,
Stricker 1989, Matson et al. 2010), and this may be due to a combination of chemical and physical characteristics of these algae and active choice of particular locations on a blade by settling larvae (Abelson 1997). Previous studies in our region have recorded events of high settlement that can lead to population outbreaks resulting in high percentage cover of the bryozoan on kelps (Saunders \& Metaxas 2008, Saunders et al. 2010). In the present study, we found that the magnitude of settlement on Fucus spp. that occurred in situ can equal or even exceed that measured on kelps under certain conditions. Larvae of $M$.

Table 5. Three-way ANOVA examining the effects of algal taxon (fixed factor, 3 levels: Saccharina latissima, Laminaria digitata, Fucus spp.), site (fixed factor, 4 levels: Feltzen South, Birchy Head, Paddy's Head, Sandy Cove) and season (fixed factor, 2 levels: December 2008, June 2009) on area of colony cover $\left(\mathrm{cm}^{2} \mathrm{~m}^{-2}\right.$ seabed) by Membranipora membranacea. Abbreviations are as in Table 3; bold font indicates significant p-values, $\alpha=0.01$ (see 'Materials and methods'). Only significant differences in post hoc tests are shown (at $\mathrm{p}<0.05)$

\begin{tabular}{|c|c|c|c|c|c|}
\hline Effect & MS & $F_{\mathrm{df}}$ & $\mathrm{p}$ & \multicolumn{2}{|c|}{ Tukey's HSD test } \\
\hline Algal taxon & 32.22 & $16.09_{2,213}$ & $<0.001$ & $\begin{array}{l}\mathrm{BH} \\
\mathrm{FS} \\
\mathrm{PH} \\
\mathrm{SC}\end{array}$ & $\begin{array}{l}\text { Jun 09: } F S>L d, S l \\
\text { Jun 09: } F S>L d, S l ; L d>S l \\
\text { Dec 08: } L d>S l, F S \\
\text { Jun 09: } F S, L d>S l \\
\text { Dec 08: } L d, S l>F S\end{array}$ \\
\hline Site & 8.781 & $4.386_{3,213}$ & 0.005 & $\begin{array}{l}S 1 \\
L d \\
F S\end{array}$ & $\begin{array}{l}\text { Dec 08: } \mathrm{BH}>\mathrm{FS} \\
\text { Jun 09: } \mathrm{FS}>\mathrm{BH}, \mathrm{SC} ; \mathrm{PH}>\mathrm{BH} \\
\text { Dec 08: } \mathrm{BH}>\mathrm{FS}, \mathrm{PH}, \mathrm{SC} \\
\text { Jun 09: } \mathrm{FS}>\mathrm{BH}, \mathrm{PH}>\mathrm{SC}\end{array}$ \\
\hline Season & 259.1 & $129.4_{1,213}$ & $<0.001$ & $\begin{array}{l}S l \\
L d \\
F S\end{array}$ & $\begin{array}{l}\text { All sites: Dec } 08>\text { Jun } 09 \\
\text { BH, PH, SC: Dec } 08>\text { Jun } 09 \\
\text { BH, SC: Dec } 08>\text { Jun } 09 \\
\text { FS: Dec } 08<\text { Jun } 09\end{array}$ \\
\hline Algal taxon $\times$ Site & 16.69 & $8.333_{6,213}$ & $<0.001$ & & \\
\hline Algal taxon $\times$ Season & 45.42 & $22.68_{2,213}$ & $<0.001$ & & \\
\hline Site $\times$ Season & 25.07 & $12.52_{3,213}$ & $<0.001$ & & \\
\hline Algal taxon $\times$ Site $\times$ Season & 3.410 & $1.703_{6,213}$ & 0.122 & & \\
\hline Error & 2.002 & & & & \\
\hline
\end{tabular}


Table 6. Two-way ANOVA examining the effects of algal taxon (fixed factor, 3 levels: Saccharina latissima, Laminaria digitata, Fucus spp.) and site (fixed factor, 4 levels: Feltzen South, Birchy Head, Paddy's Head, Sandy Cove) on prewinter colony cover $\left(\mathrm{cm}^{2} \mathrm{~m}^{-2}\right.$ alga and $\mathrm{cm}^{2} \mathrm{~m}^{-2}$ seabed) in November and December 2008, by Membranipora membranacea. Abbreviations are as in Table 3; bold font indicates significant $p$-values, $\alpha=0.01$ (see 'Materials and methods'). Only significant differences in post hoc tests are shown (at $\mathrm{p}<0.05)$

\begin{tabular}{|lcccl|}
\hline Effect & MS & $F_{\mathrm{df}}$ & $\mathrm{p}$ & \multicolumn{1}{c|}{ Tukey's HSD test } \\
\hline Cover (per unit area alga) & & & \\
Algal taxon & 59.61 & $33.43_{2,105}$ & $\mathbf{< 0 . 0 0 1}$ & $\mathrm{Ld}>\mathrm{Sl}>\mathrm{FS}$ \\
Site & 24.30 & $13.63_{3,105}$ & $\mathbf{< 0 . 0 0 1}$ & $\mathrm{BH}>\mathrm{PH}, \mathrm{SC}, \mathrm{FS}$ \\
Algal taxon $\times$ Site & 3.217 & $1.804_{6,105}$ & 0.105 & \\
Error & 1.783 & & & \\
Cover (per unit area seabed) & & & \\
Algal taxon & 39.78 & $20.49_{2,105}$ & $\mathbf{< 0 . 0 0 1}$ & $\mathrm{Ld}>\mathrm{Sl}>\mathrm{FS}$ \\
Site & 17.31 & $8.918_{3,105}$ & $\mathbf{< . 0 0 1}$ & $\mathrm{BH}>\mathrm{PH}, \mathrm{SC}, \mathrm{FS}$ \\
Algal taxon $\times$ Site & 4.478 & $2.307_{6,105}$ & 0.039 & \\
Error & 1.941 & & & \\
\hline
\end{tabular}

ment on taxa other than kelp may be further increased by limitation of space for settlement on the few remaining kelps.

\section{Prewinter cover}

Despite the variation in patterns of settlement, by late autumn, prewinter cover was generally distributed similarly among sites and was greatest on Laminaria digitata and lowest on Fucus spp., suggesting differences exist among these taxa either in the growth or loss of colonies. Loss of colonies via erosion is lower on L. digitata than on Saccharina latissima (Saunders \& Metaxas 2009b), and differential growth of bryozoan colonies has not been observed between

membranacea can be physically filtered by high kelps, which will then decrease larval supply beneath the canopy in kelp beds or beyond the kelp beds and nearer to shore (Bernstein \& Jung 1979, Duggins et al. 1990). Consequently, settlers are likely to be abundant on Fucus spp. where kelps are sparse or distributed separately, as a result of the absence of this 'kelp filtration' effect. Where kelps are particularly sparse, as under severe defoliation (Saunders \& Metaxas 2009b), it is possible that levels of settle- the kelps (Saunders \& Metaxas 2009b). However, several differences between kelps and Fucus make differential growth between these 2 substrata types likely. Whereas space is abundant on kelps, Fucus thalli are relatively small and divided by branching. Additionally, space is more likely to be occupied by other epifauna on Fucus spp. because of the slower growth and the stability of this alga, than on kelps (Yorke \& Metaxas 2011). Growth of Membranipora membranacea is probably limited on Fucus spp. as a

Table 7. Three-way ANOVA examining the effects of algal taxon (fixed factor, 3 levels: Saccharina latissima, Laminaria digitata, Fucus spp.), site (fixed factor, 4 levels: Feltzen South, Birchy Head, Paddy's Head, Sandy Cove) and year (random factor, 2 levels: 2008, 2009) on postwinter colony cover $\left(\mathrm{cm}^{2} \mathrm{~m}^{-2}\right.$ seabed) in July 2008 and July 2009, by Membranipora membranacea. Abbreviations are as in Table 3 ; bold font indicates significant $p$-values, $\alpha=0.01$ (see 'Materials and methods'). Only significant differences in post hoc tests are shown (at $\mathrm{p}<0.05$ )

\begin{tabular}{|c|c|c|c|c|c|}
\hline Effect & MS & $F_{\mathrm{df}}$ & $\mathrm{p}$ & \multicolumn{2}{|c|}{ Tukey's HSD test } \\
\hline Algal taxon & 68.358 & $235.4_{2,2}$ & 0.004 & $\begin{array}{l}\mathrm{FS} \\
\mathrm{BH} \\
\mathrm{PH}\end{array}$ & $\begin{array}{l}\text { 2008: } F S>L d, S l \\
\text { 2009: } F S>L d>S l \\
\text { 2008: } L d, F S>S l \\
\text { 2009: } F S>L d, S l \\
\text { 2009: } L d, F S>S l\end{array}$ \\
\hline Site & 34.497 & $2.192_{3,3}$ & 0.268 & $\begin{array}{l}L d \\
F S\end{array}$ & $\begin{array}{l}\text { 2008: } \mathrm{BH}>\mathrm{PH}, \mathrm{FS}, \mathrm{SC} \\
\text { 2009: } \mathrm{FS}>\mathrm{SC}, \mathrm{BH} ; \mathrm{PH}>\mathrm{BH} \\
\text { 2008: } \mathrm{FS}>\mathrm{BH}>\mathrm{PH}, \mathrm{SC} \\
\text { 2009: } \mathrm{FS}>\mathrm{BH}, \mathrm{PH}>\mathrm{SC}\end{array}$ \\
\hline Year & 6.657 & $0.862_{1,0.64}$ & 0.585 & $\begin{array}{l}L d \\
F S\end{array}$ & $\begin{array}{l}\text { FS, SC: } 2008<2009 \\
\text { BH: } 2008>2009 \\
\text { PH: } 2008<2009\end{array}$ \\
\hline Algal taxon $\times$ Site & 23.994 & $2.885_{6,6}$ & 0.111 & & \\
\hline Algal taxon $\times$ Year & 0.290 & $0.035_{2,6.00}$ & 0.966 & & \\
\hline Site $\times$ Year & 15.736 & $1.895_{3,6.01}$ & 0.231 & & \\
\hline Algal taxon $\times$ Site $\times$ Year & 8.318 & $4.496_{6,207}$ & $<0.001$ & & \\
\hline Error & 1.850 & & & & \\
\hline
\end{tabular}


result of reduced space availability, and restriction of colony size and growth rate on this algal substratum (Saunders \& Metaxas 2009a, Yorke \& Metaxas 2011).

\section{Postwinter cover}

At the end of winter, cover of the invasive bryozoan was greater overall on Fucus spp. than on kelps at most sites. Kelps grow basally and erode distally, and growth of kelps in this region is particularly rapid in late winter and early spring (Mann 1972, Krumhansl \& Scheibling 2011), resulting in the replacement of frond tissue and shedding of epifauna. The incidence of postwinter cover on kelps reported here is principally due to retention of colonies on stipes and the bases of fronds. Conversely, growth of fucoids is apical with minimal erosion and breakage, and growth occurs exclusively during summer when active photosynthesis is possible (Mann 1973). Overwintered Membranipora membranacea on Fucus spp. was greatest at Feltzen South, and this was associated with high abundance of $F$. serratus at that site. Despite site-specific and annual variation, where settlement and growth of $M$. membranacea occur on Fucus spp., and where this alga occurs in abundance, Fucus represents an important refuge for the overwintering of colonies in this region.

\section{Potential role of Fucus in bryozoan population dynamics}

Although invasive species with a larval dispersal phase, such as Membranipora membranacea, are more likely to be successful (Ricciardi \& Rasmussen 1998), range expansion is often narrower than predicted based on ocean circulation alone (Grosholz 1996), indicating that other factors can also play significant roles in invasion success. Space availability has been identified as a critical limiting resource that affects the susceptibility of a community to the establishment of nonnative species in marine subtidal habitats (Stachowicz et al. 1999, Chavanich \& Harris 2000). The utilization of Fucus as an alternative substratum to kelp for $M$. membranacea can influence the population dynamics of this invasive bryozoan in several ways and provide a mechanism for the lack of evidence of its decline through kelp defoliation (as suggested by Levin et al. 2002).

We propose that successful overwintering on Fucus is important to the population dynamics of Membranipora membranacea in Nova Scotia, particularly in years when severe defoliation removes colonies on kelps. Where defoliation has been severe enough to prevent regrowth of kelps in the following season, Fucus can also provide an alternative substratum for settlement and growth. Additionally, physical characteristics of Fucus substrata probably accelerate reproduction in $M$. membranacea. Whereas colonies of $M$. membranacea normally do not become reproductive until they are large and mature $\left(\sim 2500 \mathrm{~mm}^{2}\right.$, aged 40 to $60 \mathrm{~d}$ in the eastern Pacific Ocean) (Harvell 1992), colonies that are crowded by conspecifics reproduce sexually regardless of colony size and age (Harvell \& Grosberg 1988). Colonies of M. membranacea on Fucus spp. in Nova Scotia may therefore reproduce earlier in the season than those on kelps, supplying larvae that can settle on kelps in spring and early summer.

Settlement, growth and overwintering of Membranipora membranacea on Fucus spp. may also have implications for the local spread of this invasive bryozoan. Although kelps are relatively continuously distributed along the Atlantic coast of Nova Scotia, there are areas in the region where kelps are sparse or absent and algal assemblages are dominated by Fucus spp. (e.g. the northern tip of the northeastern shore of mainland Nova Scotia and on Cape Breton Island, Watanabe et al. 2009). Although the patterns in ocean circulation are not well known, this a topographically complex region where different currents (e.g. Labrador Current, Nova Scotia Current, outflow of the Gulf of St Lawrence and the Northumberland Strait) interact. Additionally, larval abundance of $M$. membranacea is lower in this region than on the rest of the Atlantic coast of Nova Scotia (Saunders \& Metaxas 2010, A. Metaxas unpubl. data) and the species is absent on the western coast of Cape Breton Island and into Northumberland Strait (A. Metaxas pers. obs.). The presence of $M$. membranacea on both $F$. evanescens and $F$. serratus suggests that these algae can provide a significant vector for range expansion of this bryozoan across these regions, which may alternatively present potential dispersal bottlenecks.

\section{CONCLUSIONS}

Our study suggests that an understanding of the population dynamics of Membranipora membranacea in any nonnative region should extend beyond kelps to include the occurrence of this invasive bryozoan on Fucus spp. and possibly other algal taxa. The relative importance of kelp and fucoid substrata 
varies both intra- and interannually, as well as spatially. Given the abundant settlement on both kelps and Fucus spp., Fucus can be an important substratum for settlement, particularly at locations with low kelp abundance, as would be the case where defoliation of kelps has been extensive. Quantification of $M$. membranacea on these algal taxa has expanded our understanding of the population dynamics of this bryozoan in a nonnative region and has revealed mechanisms that contribute to the success and spread of this invasive species.

Acknowledgements. Research was conducted with field assistance from J. Lindley, M. Saunders, S. Watanabe, K. Krumhansl, L. Sauchyn, R. Daigle, K. Dinning, J. Short, V. Burdett-Coutts, S. Henderson, M. Lloyd and D. Lyons, and laboratory assistance from A. Roy, J. Short, K. Dinning and S. Henderson. We thank the staff of the Dalhousie University Aquatron facility for laboratory space and equipment. This research was supported by a Natural Sciences and Engineering Research Council (NSERC) Discovery grant to A.M. and a NSERC Canada Graduate Scholarship, a Killam Predoctoral Fellowship and a Dalhousie University President's Award to A.Y.

\section{LITERATURE CITED}

Abelson A (1997) Settlement in flow: upstream exploration of substrata by weakly swimming larvae. Ecology 78 : 160-166

Berman J, Harris L, Lambert W, Buttrick M, Dufresne M (1992) Recent invasions of the Gulf of Maine: three contrasting ecological histories. Conserv Biol 6:435-441

$>$ Bernstein BB, Jung J (1979) Selective pressures and coevolution in a kelp canopy community in southern California. Ecol Monogr 49:335-355

Chavanich S, Harris LG (2000) Potential impact of the introduced bryozoan, Membranipora membranacea, on the subtidal snail, Lacuna vincta, in the Gulf of Maine. In: Pederson J (ed) Marine bioinvasions: proceedings of the first national conference. Massachusetts Institute of Technology Sea Grant College Program, Cambridge, MA, p 157-163

$>$ Duggins DO, Eckman JE, Sewell AT (1990) Ecology of understory kelp environments. II. Effects of kelps on recruitment of benthic invertebrates. J Exp Mar Biol Ecol 143:27-45

Edelstein T, Greenwell M, Bird CJ, McLachlan J (1971) Investigations of the marine algae of Nova Scotia. X. Distribution of Fucus serratus L. and some other species of Fucus in the Maritime Provinces. Proc NS Inst Sci 27: 33-42

> Grosholz ED (1996) Contrasting rates of spread for introduced species in terrestrial and marine systems. Ecology 77:1680-1686

> Harris LG, Tyrrell MC (2001) Changing community states in the Gulf of Maine: synergism between invaders, overfishing and climate change. Biol Invasions 3:9-21

> Harvell CD (1992) Inducible defenses and allocation shifts in a marine bryozoan. Ecology 73:1567-1576

> Harvell CD, Grosberg RK (1988) The timing of sexual matu- rity in clonal animals. Ecology 69:1855-1864

> Krumhansl KA, Scheibling RE (2011) Detrital production in Nova Scotian kelp beds: patterns and processes. Mar Ecol Prog Ser 421:67-82

- Krumhansl KA, Lee JM, Scheibling RE (2011) Grazing damage and encrustation by an invasive bryozoan reduce the ability of kelps to withstand breakage by waves. J Exp Mar Biol Ecol 407:12-18

Lambert W, Levin PS, Berman J (1992) Changes in the structure of a New England (USA) kelp bed: the effects of an introduced species? Mar Ecol Prog Ser 88:303-307

Levin PS, Coyer JA, Petrik R, Good TP (2002) Communitywide effects of nonindigenous species on temperate rocky reefs. Ecology 83:3182-3193

Mann KH (1972) Ecological energetics of the seaweed zone in a marine bay on the Atlantic coast of Canada. II. Productivity of the seaweeds. Mar Biol 14:199-209

> Mann KH (1973) Seaweeds: their productivity and strategy for growth. Science 182:975-981

> Matson PG, Steffen BT, Allen RM (2010) Settlement behavior of cyphonautes larvae of the bryozoan Membranipora membranacea in response to two algal substrata. Invertebr Biol 129:277-283

McCook LJ, Chapman ARO (1991) Community succession following massive ice-scour on an exposed rocky shore: effects of Fucus canopy algae and of mussels during late succession. J Exp Mar Biol Ecol 154:137-169

McDevit DC, Saunders GW (2010) A DNA barcode examination of the Laminariaceae (Phaeophyceae) in Canada reveals novel biogeographical and evolutionary insights. Phycologia 49:235-248

O'Connor RJ, Seed R, Boaden PJS (1979) Effects of environment and plant characteristics on the distribution of bryozoa in a Fucus serratus L. community. J Exp Mar Biol Ecol 38:151-178

> Ricciardi A, Rasmussen JB (1998) Predicting the identity and impact of future biological invaders: a priority for aquatic resource management. Can J Fish Aquat Sci 55: 1759-1765

Ryland JS (1959) Experiments on the selection of algal subsrates by polyzoan larvae. J Exp Biol 36:613-631

Ryland JS (1962) The association between polyzoa and algal substrata. J Anim Ecol 31:331-338

Ryland JS, Stebbing ARD (1971) Settlement and orientated growth in epiphytic and epizoic bryozoans. In: DJ Crisp (ed) Fourth European marine biology symposium. Cambridge University Press, Cambridge, p 105-123

Saier B, Chapman AS (2004) Crusts of the alien bryozoan Membranipora membranacea can negatively impact spore output from native kelps (Laminaria longicruris). Bot Mar 47:265-271

Sakai AK, Allendorf FW, Holt JS, Lodge DM and others (2001) The population biology of invasive species. Annu Rev Ecol Syst 32:305-332

> Saunders M, Metaxas A (2007) Temperature explains settlement patterns of the introduced bryozoan Membranipora membranacea in Nova Scotia, Canada. Mar Ecol Prog Ser 344:95-106

Saunders M, Metaxas A (2008) High recruitment of the introduced bryozoan Membranipora membranacea is associated with kelp bed defoliation in Nova Scotia, Canada. Mar Ecol Prog Ser 369:139-151

Saunders MI, Metaxas A (2009a) Effects of temperature, size, and food on the growth of Membranipora membranacea in laboratory and field studies. Mar Biol 
156:2267-2276

Saunders MI, Metaxas A (2009b) Population dynamics of a nonindigenous epiphytic bryozoan Membranipora membranacea in the western North Atlantic: effects of kelp substrate. Aquat Biol 8:83-94

Saunders MI, Metaxas A (2010) Physical forcing of bryozoan larval distributions in a coastal embayment. Mar Ecol Prog Ser 418:131-145

Saunders MI, Metaxas A, Filgueira R (2010) Implications of warming temperatures for population outbreaks of a nonindigenous species (Membranipora membranacea, Bryozoa) in rocky subtidal ecosystems. Limnol Oceanogr 55:1627-1642

Scheibling RE, Gagnon P (2006) Competitive interactions between the invasive green alga Codium fragile ssp. tomentosoides and native canopy-forming seaweeds in Nova Scotia (Canada). Mar Ecol Prog Ser 325:1-14

Scheibling RE, Gagnon P (2009) Temperature-mediated outbreak dynamics of the invasive bryozoan Membranipora membranacea in Nova Scotian kelp beds. Mar Ecol Prog Ser 390:1-13

Scheibling RE, Hennigar AW, Balch T (1999) Destructive grazing, epiphytism, and disease: the dynamics of sea urchin-kelp interactions in Nova Scotia. Can J Fish Aquat Sci 56:2300-2314

Schwaninger HR (1999) Population structure of the widely dispersing marine bryozoan Membranipora membranacea (Cheilostomata): implications for population his-

Editorial responsibility: Christine Paetzold,

Oldendorf/Luhe, Germany tory, biogeography, and taxonomy. Mar Biol 135:411-423

Seed R (1976) Observations on the ecology of Membranipora (Bryozoa) and a major predator Doridella steinbergae (Nudibranchiata) along the fronds of Laminaria saccharina at Friday Harbor, Washington. J Exp Mar Biol Ecol 24:1-17

Stachowicz JJ, Whitlatch RB, Osman RW (1999) Species diversity and invasion resistance in a marine ecosystem. Science 286:1577-1579

Stricker SA (1989) Settlement and metamorphosis of the marine bryozoan Membranipora membranacea. Bull Mar Sci 45:387-405

- Walters LJ, Wethey DS (1986) Surface topography influences competitive hierarchies on marine hard substrata: a field experiment. Biol Bull (Woods Hole) 170:441-449

Watanabe S, Scheibling RE, Metaxas A (2009) Contrasting patterns of spread in interacting invasive species: Membranipora membranacea and Codium fragile off Nova Scotia. Biol Invasions 12:1-14

Wright JT, Davis AR (2006) Demographic feedback between clonal growth and fragmentation in an invasive seaweed. Ecology 87:1744-1754

Yorke AF, Metaxas A (2011) Interactions between an invasive and a native bryozoan (Membranipora membranacea and Electra pilosa) species on kelp and Fucus substrates in Nova Scotia. Mar Biol 158:2299-2311

Zar JH (1999) Biostatistical analysis. Prentice-Hall, Upper Saddle River, NJ

Submitted: July 11, 2011; Accepted: February 17, 2012

Proofs received from author(s): May 27, 2012 